\title{
Application of selected teak clone and organic fertilizer to accelerate rehabilitation of lowland forest in Java, Indonesia
}

\author{
SURYO HARDIWINOTO, FIQRI ARDIANSYAH, WIDIYATNO \\ Department of Silviculture, Faculty of Forestry, Universitas Gadjah Mada. Jl. Agro, Bulaksumur, Sleman 55281, Yogyakarta, Indonesia. \\ Tel.: +62-274-550541, ‘email: widiyatno@ugm.ac.id
}

Manuscript received: 16 December 2020. Revision accepted: 11 March 2021

\begin{abstract}
Hardiwinoto S, Ardiansyah F, Widiyatno. 2021. Application of selected teak clone and organic fertilizer to accelerate rehabilitation of lowland forest of Java, Indonesia. Biodiversitas 22: 1750-1756. Lowland forest in Java Island Indonesia is dominated by teak forest. However, for some decades, the forest has degraded and decreased teak wood production. Rehabilitation of the degraded forest is needed to accelerate the forest land cover. Vegetative propagation of selected clones is one of the techniques used in the asexual reproduction of plants to maintain superior genetics from ancestors to their offspring. In addition, adding organic fertilizer can improve the chemical and physical properties of degraded sites. In this study, vegetative propagation techniques of selected teak clones and addition of organic fertilizer were used to rehabilitate the degraded forest. The objectives of the research were to determine the best propagation technique and appropriate dosage of organic fertilizer toward the early growth of clonal teak plantations. The results showed that the height and diameter parameters did not significantly differ for vegetative propagation and interaction with organic fertilizer dosage $(\mathrm{P}>0.05)$. However, the dosage of organic fertilizer significantly increased the DBH of the teak $(\mathrm{P}<0.05)$, although the height parameter did not significantly differ among dosages of organic fertilizer $(\mathrm{P}>0.05)$. The best dosage of organic fertilizer was $5 \mathrm{~kg}$ /individual, under which the average growth in height and diameter of teak at 14 months was 3.79 and $5.60 \mathrm{~cm}$, respectively. This suggests that vegetative propagation of selected teak clones and addition of $5 \mathrm{~kg} /$ individual organic fertilizer could be implemented to support the successful rehabilitation of degraded forests.
\end{abstract}

Keywords: Degraded forest, rehabilitation, selected teak clone, vegetative propagation, organic fertilizer

\section{INTRODUCTION}

Teak is one of the most valuable species developed in the lowland forests (Bailey et al. 2005; Pandey and Brown 2000 ), and the total area of natural and planted teak forest worldwide is 29 million ha and 4.35-6.89 million ha, respectively (Koller and Kleine 2017a)..Teak is known to have good wood quality in terms of color and texture as well as ease of wood processing and resistance to termites, mold, and weather (Kaosa-ard 1998). Worldwide demand for teak is high, with about 2.0-2.5 million cubic meters of teak roundwood harvested annually from natural and planted forests (Koller and Kleine 2017b). In Indonesia, the demand for teak is increasing because it supports the teak wood processing industry, which produces wood products such as flooring, furniture, and so on. Unfortunately, teak wood production has recently declined, especially in natural forests, due to overcutting, agricultural expansion, grazing, etc. (Koller and Kleine 2017b). In Indonesia, forest degradation in Java Island dominated by teak forest was more than 14,000 ha.year $^{-1}$ and dominated by young age classes of tree (MOEF 2019). Thus, the deficit of teak wood was more than 2,000,000 $\mathrm{m}^{3}$ per year (Iskak 2005), resulting in the instability of the teak wood processing industry.

Forest rehabilitation aims to restore the capacity of degraded land to produce the forest products and services of a forest (ITTO 2002). One benefit of forest rehabilitation improves the economic value of degraded forests that use the species suitable for existing or potential markets (ITTO 2001; Lamb and Gilmour 2003). To address the rehabilitation of degraded lowland forests in Java island, selected clonal teak material should be used to support the success of rehabilitation program to increase forest productivity and forest land cover (Evans 2009; Evans and Turnbull 2004). On the other hand, the soil characteristic of Java lowland forest is suitable for teak plantation (Tanaka et al. 1998).

Clonal forestry of teak begins with plant breeding. The teak breeding program in Indonesia was initiated by establishing cooperation between the Faculty of Forestry UGM and Perum Perhutani in the 1980s. This program has successfully collected 600 plus trees from all teak distributed in Indonesia, both inside and outside Java. Thus, the plus trees of teak were established as the clonal bank, progeny test, and ex-situ teak conservation model. The results of progeny and clonal test showed that the selected teak clones could grow well at various sites (Na'iem 2012) and grow well in degraded areas, with annual diameter increase of $>3 \mathrm{~cm}$ (Budiadi et al. 2017). This technique is expected to improve rehabilitation success using selected teak clones in Java, which currently has $3 \mathrm{~m}^{3} \mathrm{ha}^{-1}$ year ${ }^{-1}$ (Pandey and Brown 2000).

Studies on clonal forestry of teak have mainly focused on selection techniques for superior teak cloning (Palanisamy et al. 2009), seed propagation techniques for teak clones in nurseries (Goh et al. 2007; Adinugraha and Mahfudz 2014), and the effects of IBA dosage on clone 
rooting (Guleria and Varshisht 2014; Badilla et al. 2016). The effects of different vegetative propagation techniques (budding and shoot cutting) from selected teak clone material on growth performance in the field have rarely been explored. This study is important in determining the differences in plant growth based on different vegetative techniques in order to support the large-scale rehabilitation program using the selected teak clone in the degraded forest. Moreover, a previous study on coffee plant propagation showed that plant material developed from grafting (the presence of rootstock from seeds) produces better and more adaptive plant growth than shoot cuttings. This assumes that the root-stock developed from seeds or sexual reproduction has a relatively better root system than shoot cuttings (Júnior et al. 2013).

The types of degraded land are poor in their physical, chemical and biological soil properties ( $\mathrm{Li}$ et al. 2013), so rehabilitation of degraded forest needs special requirements, i.e. selected clone and fertilizer to accelerate forest rehabilitation. The degraded forest with soil type of Vertisols (grumusols) has poor aeration and slow drainage as well as a sticky and plastic wet season consistency. This soil type shrinks when dry and swells when wet owing to its high clay content, which inhibits soil cultivation (Chesworth 2008). One of techniques to improve the degraded site condition is to use organic fertilizer. A study of fertilizer on teak plantations in Thailand showed that the growth of teak with application of dolomite, $1 \mathrm{~kg}$ per tree organic fertilizer, $200 \mathrm{~g}$ per tree chemical fertilizer, or control did not statistically differ (Wichiennopparat et al. 2012). Fertilizer is essential because teak grows well on sites with good soil, good aeration, and drainage (Sukchan and Noda 2012). The use of organic fertilizer can increase the content of organic matter and humus in the soil and improve soil physical properties, especially soil structure (Fageria 2012), water-holding capacity, soil porosity, and soil fertility (Xu et al. 2013). Therefore, the study on rehabilitation of degraded forests using selected teak clones had the primary purpose of determining their growth using the vegetative propagation techniques and improving the sites with organic fertilizer. It is expected to contribute to the success of rehabilitation programs in degraded forests.

\section{MATERIALS AND METHODS}

\section{Study area}

The study was established in the Wanagama Educational Forest, Gunung Kidul District, Yogyakarta (Figure 1), a degraded forest area and Vertisols. Seedlings of selected teak clones were obtained using vegetative propagation techniques, namely: shoot cutting and budding. Organic fertilizer was applied to improve the site quality of the degraded site. The study used a factorial randomized complete block design (RCBD), where the first factor was the technique of teak vegetative propagation (shoot cutting, and budding), and the second factor was the dosage of organic fertilizer $(0,1,3$, and $5 \mathrm{~kg}$ per individual), with four blocks as replications. The measurement of the test plot per treatment was in the square plot form $(5 \times 5$ plants). The seedling was propagated by shoot cutting and budding and maintained for 6 months in nursery. Spacing of teak plantation was $3 \mathrm{~m} \times 3 \mathrm{~m}$.

\section{Procedures and data analysis}

Measurements of tree height and diameter were conducted when plants were 7 and 14 months old. The data were analyzed using SAS 9.0 software using analysis of variance (ANOVA) with RCBD (Randomized Complete Block Design) factorial design. The difference between treatments was analyzed using a Duncan Multiple Range Test (DMRT) at a significance level of $5 \%$.

Soil sample collection at the test location was conducted to determine the initial status of soil fertility for use as a reference with regard to the addition of organic matter. Soil sampling was carried out randomly at the test location at three locations, and each soil sample was collected at three soil depths: $0-10 \mathrm{~cm}, 11-20 \mathrm{~cm}$, and $21-$ $30 \mathrm{~cm}$. Soil samples taken from each depth were weighed $( \pm 0.5 \mathrm{~kg})$ and analyzed in the soil laboratory. Samples of organic fertilizer were also collected and the chemical properties of the nutrients were analyzed. The chemical properties of the soil and organic fertilizer observed and measured in this study were $\mathrm{pH}$ and $\mathrm{N}, \mathrm{P}$, and $\mathrm{K}$ content. The $\mathrm{pH}$ value was determined by $\mathrm{pH} \mathrm{H}_{2} \mathrm{O}$ with a soil: solution ratio of $1: 2.5$ by using glass electrodes. $\mathrm{N}$ and $\mathrm{P}$ content were measured using the Kjeldahl and Bray method, while $\mathrm{K}$ was measured by the $25 \% \mathrm{HCl}$ method (Sulaeman et al. 2005).

\section{RESULTS AND DISCUSSION}

\section{Vegetative propagation techniques}

The different vegetative propagation techniques had no significant effect on height and diameter parameters $(P>$ 0.05 , Tables 1 and 2) at 7 and 14 months after planting. The height growth of the budding and shoot cutting treatments at the age of 14 months was $2.99 \mathrm{~m}$ and $2.79 \mathrm{~m}$, respectively (Figure 2.A). Meanwhile, the diameter growth of budding and shoot cuttings was $4.66 \mathrm{~cm}$ and $4.60 \mathrm{~cm}$, respectively (Figure 2.B).

The non-significant difference between the vegetative techniques was due to the vegetative propagation techniques used as they involve copying the genome of the parent tree, which produces individuals having similar traits to those of their parent tree. Thus, they can maintain the genetic superiority of the parent tree, reduce the problem of seed germination and control plant growth (Wiesman and Jaenicke 2002). 


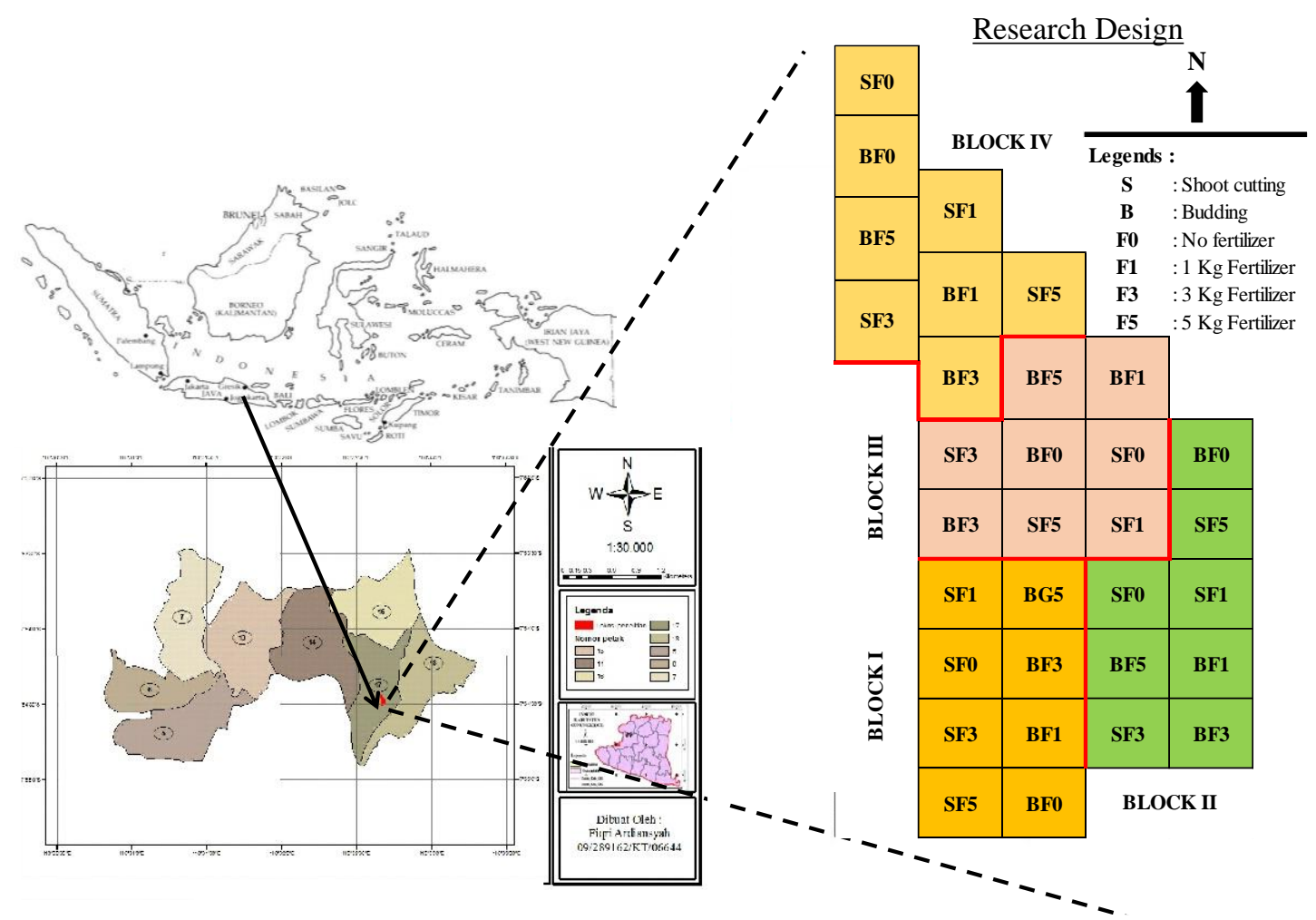

Figure 1. Study area established in the Wanagama Educational Forest, Gunung Kidul District, Yogyakarta, Indonesia and research design

This result showed an assumption that budding would provide better growth than shoot cuttings because the buds had more roots, which was not statistically proven. However, there was a tendency toward better growth of plants derived from budding as compared to those grown from shoot cuttings. These results also suggest that plant propagation with shoot cuttings can be used to support large-scale teak clonal forestry because it is more advantageous than budding in some ways, such as the ease of obtaining shoot cuttings through a hedge orchard. This technique also requires smaller amounts of rootstock as compared to budding (Högberg 2003). The multiplication of teak clones is a strategy to produce uniformity of teak plants from superior-quality plants. Even though vegetative propagation tends to have relatively high costs compared to generative propagation (Högberg 2003), it is more profitable for forest management than generative propagation (Goh and Monteuuis 2005). Vegetative propagation from superior teak could also increase diameter growth by more than $300 \%$ compared to teak developed by generative propagation (Goh and Monteuuis 2005; Palanisamy et al. 2009; Na'iem 2012). Furthermore, the growth of selected teak clones by vegetative propagation was $135 \%$ greater than the teak growth was in Mae Moh Plantation, Lampang province, Thailand propagated by coppice and stump planting (Auykim et al. 2017). It suggested that our treatment would increase and accelerate the land cover of lowland degraded forests in Java. Thus, vegetative propagation by shoot cutting, especially for large-scale forestry plantations, has high economic value because vegetative propagation techniques can retain the superiority of a particular trait of an individual (Dawson 2002), which results in high stand potential at the end of the cycle (Evans and Turnbull 2004).

The organic fertilizer dosage significantly differed among the diameter variable treatments at 7 and 14 months after planting $(P<0.05$, Table 1). However, this treatment was not significantly different for the height growth of teak $(P>0.05$, Table 2). The best fertilizer dosage for the height and diameter variables was $5 \mathrm{~kg}$ organic fertilizer per individual in all treatments. Thus, the growth in height and diameter at 14 months after planting was $3.79 \mathrm{~m}$ and 5.60 $\mathrm{cm}$ (Figure 3a,b) respectively.

Table 1. ANOVA of planting material and fertilizer dosage at 7 and 14 months after planting for the diameter parameter

\begin{tabular}{lccccc}
\hline \multirow{2}{*}{ Sources } & \multirow{2}{*}{ df } & \multicolumn{2}{c}{ F value } & \multicolumn{2}{c}{$\boldsymbol{P}>\boldsymbol{F}$} \\
\cline { 3 - 6 } & & $\mathbf{7}$ months & $\mathbf{1 4}$ months & $\mathbf{7}$ months & $\mathbf{1 4}$ months \\
\hline Block & 3 & 1.18 & 8.45 & & \\
Vegetative Propagation Technique (VPT) & 1 & 0.79 & 0.20 & $0.38^{\text {ns }}$ & $0.66^{\mathrm{ns}}$ \\
Fertilizer Dosage (FD) & 3 & 2.43 & 3.06 & $0.05^{*}$ & $0.05^{*}$ \\
VTP X FD & 3 & 0.12 & 0.64 & $0.95^{\text {ns }}$ & $0.60^{\text {ns }}$ \\
\hline
\end{tabular}

Note. ns: no significant difference among treatments at t $\alpha .05 ; *$ : significant difference among treatments at t $\alpha 0.05$ 
Table 2. ANOVA of planting material and fertilizer dosage at 7 and 14 months after planting for the height parameter

\begin{tabular}{lccccc}
\hline \multirow{2}{*}{ Sources } & \multirow{2}{*}{ df } & \multicolumn{2}{c}{ F value } & \multicolumn{2}{c}{$\boldsymbol{P}>\boldsymbol{F}$} \\
\cline { 3 - 6 } & & $\mathbf{7 ~ m o n t h s}$ & $\mathbf{1 4}$ months & $\mathbf{7 ~ m o n t h s}$ & $\mathbf{1 4}$ months \\
\hline Block & 3 & 27.91 & 0.93 & & \\
Vegetative Propagation Technique (VPT) & 1 & 0.19 & 0.77 & $0.66^{\mathrm{ns}}$ & $0.41^{\mathrm{ns}}$ \\
Fertilizer Dosage (FD) & 3 & 0.32 & 0.83 & $0.81^{\mathrm{ns}}$ & $0.51^{\mathrm{ns}}$ \\
VTP X FD & 3 & 0.14 & 0.41 & $0.94^{\mathrm{ns}}$ & $0.75^{\mathrm{ns}}$ \\
\hline
\end{tabular}

Note: ns: no significant difference among treatments at t $\alpha 0.05$

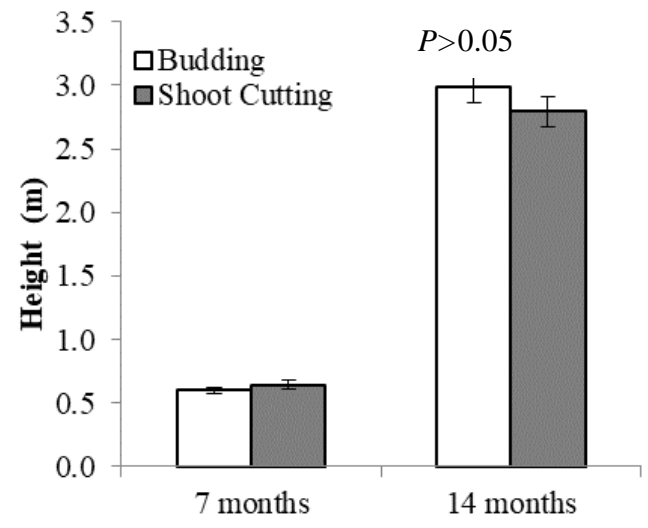

A

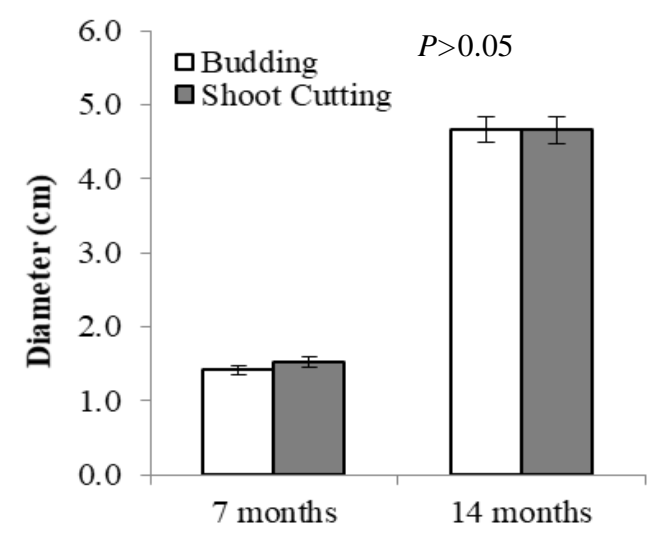

$\mathbf{B}$

Figure 2.A. The average height, and B. Diameter growth at 7 and 14 months after planting

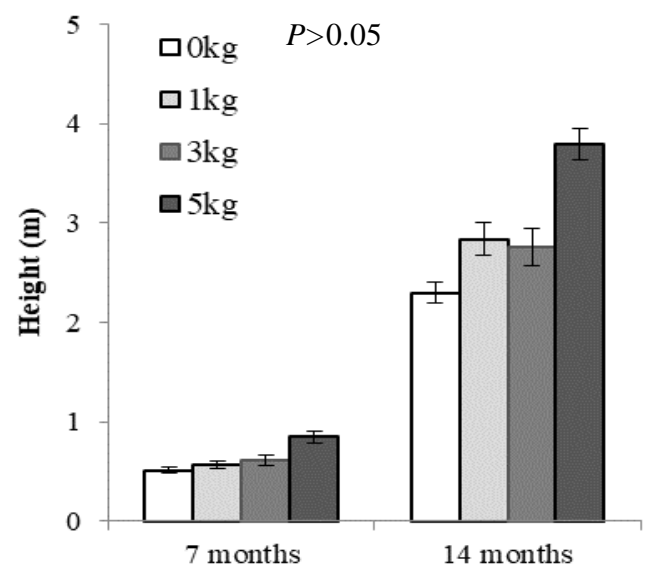

A

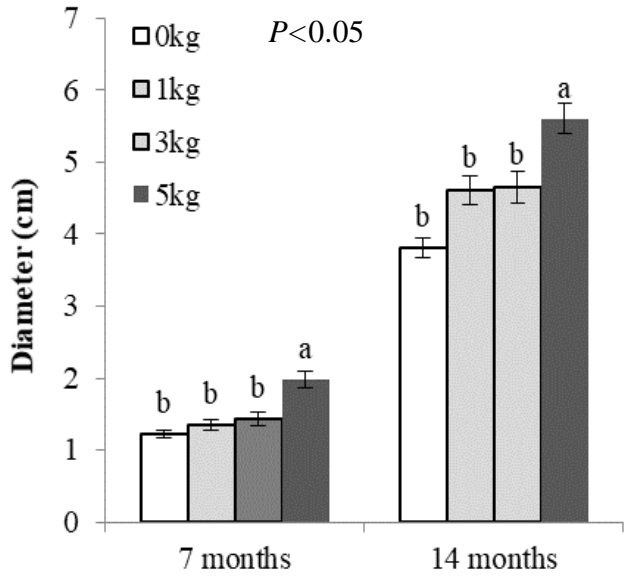

B

Figure 3. A. Effect of various organic fertilizer dosages on height, and B. Diameter growth at 7 and 14 months after planting. Letters indicate significant differences among organic fertilizer dosages (DMRT)

\section{Soil fertility status of the degraded site, and organic fertilizer}

The soils at our degraded site were Vertisols, and the content of $\mathrm{N}$ and $\mathrm{K}$ ranged from $0.16-0.18 \%$ and $0.24-0.28$ me/100 g, respectively. Meanwhile, the $\mathrm{P}$ content ranged from 16-22 ppm, and the soil $\mathrm{pH}$ at the research location was 6.84 (Table 3). Furthermore, the $\mathrm{N}$ content in organic fertilizer ranged from 1.14 to $1.16 \%$. The $\mathrm{P}$ content ranged from 1.39 to $1.46 \%$, while the $\mathrm{K}$ content ranged from 2.00 to $2.08 \%$, with a mean of $2.03 \%$ (Table 4 ).
Table 3. Soil mineral content of $\mathrm{N}, \mathrm{P}, \mathrm{K}$, and $\mathrm{pH}$ at the research site

\begin{tabular}{|c|c|c|c|c|c|c|c|}
\hline \multirow{2}{*}{$\begin{array}{c}\text { Lay } \\
\text { er }\end{array}$} & \multirow{2}{*}{$\begin{array}{c}\text { The } \\
\text { depth of } \\
\text { soil }(\mathrm{cm})\end{array}$} & \multirow{2}{*}{$\begin{array}{c}\mathbf{p H} \\
\mathbf{H}_{2} \mathrm{O}\end{array}$} & \multirow{2}{*}{$\frac{\mathrm{N} \text { total }}{\%}$} & \multicolumn{2}{|c|}{$\begin{array}{c}\text { P available } \\
\text { (Olsen) }\end{array}$} & \multicolumn{2}{|c|}{$\mathrm{K}$ available } \\
\hline & & & & ppm & $\%$ & me/100g & $\%$ \\
\hline 1 & $0-10$ & 6.84 & $0.18 * *$ & $17 * *$ & 0.0017 & $0.28 *$ & 0.0109 \\
\hline 2 & $11-20$ & 6.86 & $0.15 * *$ & $22 * *$ & 0.0022 & $0.24 *$ & 0.0093 \\
\hline 3 & $21-30$ & 6.84 & $0.16 * *$ & $16 * *$ & 0.0016 & $0.30 * *$ & 0.0117 \\
\hline
\end{tabular}


Table 4. The content of N, P, and K in organic fertilizer

\begin{tabular}{lccc}
\hline \multirow{2}{*}{ Sample } & N Total & P available & K available \\
\cline { 2 - 4 } & \multicolumn{3}{c}{$\boldsymbol{\%}$} \\
\hline S1 & 1.14 & 1.43 & 2.02 \\
S2 & 1.16 & 1.39 & 2.00 \\
S3 & 1.14 & 1.46 & 2.08 \\
Mean & 1.15 & 1.43 & 2.03 \\
\hline
\end{tabular}

Note: S1-3 were replicates of organic fertilizer samples

The soil fertility status (total $\mathrm{N}$, available $\mathrm{P}$, and available $\mathrm{K}$ ) at our research site was low, and the $\mathrm{P}$ content was categorized as medium (Sulaeman et al. 2005). On the other hand, the content of macronutrients (total $\mathrm{N}$, available $\mathrm{P}$, and available $\mathrm{K}$ ) in the organic fertilizer was much higher than that found in the soil. It was also higher than the amount needed for teak growth. This indicated that the organic fertilizer would increase nutrient availability and could supply other essential nutrients to improve tree growth (Han et al. 2016).

Teak plants can grow optimally on soil with $\mathrm{pH}>6$ (Tanaka et al. 1998; Tangmitcharoen et al. 2012). However, the low content of $\mathrm{N}, \mathrm{P}$, and $\mathrm{K}$ might have inhibited the growth of teak at the research location. The organic fertilizer dosages of 1 and $3 \mathrm{~kg} /$ plant dosage had statistically similar growth results to that of the control $(P>$ $0.05)$. The provision of organic fertilizer at a dosage of 5 $\mathrm{kg} /$ plant increased plant growth by 31.96 and $39.31 \%$, respectively, for the diameter and height variables as compared to the control (dosage $0 \mathrm{~kg} / \mathrm{plant}$ ). Organic fertilizer with a dosage of $5 \mathrm{~kg} /$ plant added $\mathrm{N}, \mathrm{P}$ and $\mathrm{K}$ elements (Table 4). These nutrients accelerated the initial growth of the teak clones. In addition to providing additional nutrients, organic fertilizer can also increase soil colloids to increase water-holding capacity, nutrient cations, and cation exchange capacity (Whalen et al. 2000).

The addition of $\mathrm{N}$ through fertilization is required to improve plant growth (Mehta et al. 2013; Wang et al. 2012) because $\mathrm{N}$ improves the growth of leaves. Thus, it increases light absorption and plant diameter development (Pinkard et al. 2007). Nitrogen (N) is one of the basic elements necessary for increasing growth and plant biomass (Wang et al. 2012). On the other hand, the excessive addition of $\mathrm{N}$ has a negative impact on plant development (Mehta et al. 2013; Wu et al. 2007; Zhou et al. 2012). In relation to the $5 \mathrm{~kg}$ dosage of organic fertilizer, the dosage was suitable for the growth of teak plants since the $\mathrm{N}$ content in the soil was very low. Furthermore, teak plants in Malaysia are still very tolerant to a provision of $\mathrm{N}$ of $200 \mathrm{~g} / \mathrm{plant}$. It provides a height and diameter increase of 33 and $66 \%$, respectively, compared to controls (Abod and Siddiqui 2002).

Phosphorus (P) is very important for plant growth, especially in teak because it influences the overall life process and the presence of plant cells. The administration of $\mathrm{P}$ through organic fertilizer has a positive effect on the growth both in height and diameter of teak clones. The addition of $\mathrm{P}$ fosters the formation of young roots, which are useful for drought resistance and increases the dry weight of leaves and leaf area index of teak plants (Abod and Siddiqui 2002). However, a lack of $P$ generally decreases the total dry weight of plants and has a negative effect on shoot and root dry weight (Brahim et al. 1996) as well as the rate of respiration and photosynthesis (Thuynsma et al. 2016). Thus, the provision of $\mathrm{P}$ for the initial growth of teak is very important in supporting plant growth.

Potassium $(\mathrm{K})$ is the third major nutrient after $\mathrm{N}$ and $\mathrm{P}$ (Chesworth 2008). The addition of $\mathrm{K}$ through organic fertilizer was stimulated plant growth in the present study and increases plant resistance to certain diseases and root systems (Wang et al. 2013). The addition of $5 \mathrm{~kg}$ organic fertilizer increased the $\mathrm{K}$ content at the research location. The provision of $5 \mathrm{~kg} /$ plant of organic fertilizer can reduce the negative impacts of deficiency of $\mathrm{K}$ in the soil on plants such as disruption of the translocation process of carbohydrate and nitrogen metabolism (Kramer and Konzlowski 1979) and inhibition of the plant photosynthesis process (Wang et al. 2013).

Adding organic fertilizer up to $5 \mathrm{~kg} /$ plant gives the best growth response and greatly helps plants in the initial phase of plant growth. This suggests that the organic fertilizer was very important in improving the availability of nutrients such as N, P and $\mathrm{K}$ and increasing teak growth, especially by overcoming the limitations of macronutrient content at the research location so that clonal forests of superior teak could maintain their growth.

\section{The implication for forest rehabilitation and conservation of teak}

Degraded forest is defined as loss of canopy cover, reduction of growing, and biomass stock (VásquezGrandón et al 2018). It implied decreasing biodiversity, carbon sequestration, and increasing greenhouse gases (Gatti et al. 2015). In order to improve the quality of degraded forests, an application of selected teak clones and organic fertilizer will accelerate forest rehabilitation in the lowland forest in Java. Vegetative propagation of selected teak clones has successfully supported the rehabilitation of degraded forests, both using shoot cutting and budding techniques. The shoot cutting is more recommended, as it is easier to handle in the nursery than a budding technique. Moreover, the degraded site rehabilitation by the addition of $5 \mathrm{~kg} /$ individual of organic fertilizer could increase the growth of the selected teak clone. The increase of height and diameter growth at 14 months after planting was 62.7 and $47.1 \%$ greater, respectively than that of the control treatment. Our treatment could accelerate land cover and improve the land productivity of degraded forests in Java in terms of forest rehabilitation. It suggested that our treatment would increase and accelerate the land cover of lowland degraded forests. On the other hand, accelerating rehabilitation also would increase wood production, ecosystem services, and species conservation (Chazdon 2008). 


\section{ACKNOWLEDGEMENTS}

The author expresses their gratitude to the Faculty of Forestry of Universitas Gadjah Mada (UGM), Yogyakarta, Indonesia for providing financial support through the DPP Research Grant to carry out this research. Our gratitude goes to the Wanagama Educational Forest and the Forest Soil Science Laboratory, Faculty of Forestry, UGM for the permission to use the facilities for conducting research. We are also indebted to our colleagues at the Silviculture and Agroforestry Laboratory, i.e.: Sukirno Priatno, Adriana, Dr. Priyono Suryanto, and Dr. Budiadi for their support, assistance, and discussion in the implementation and completion of this research.

\section{REFERENCES}

Abod SA, Siddiqui MT. 2002. Growth response of teak (Tectona grandis L.f.) seedlings to nitrogen, phosphorus and potassium fertilizers. Pertanika J Trop Agric Sci 25: 107-113.

Adinugraha HA, Mahfudz. 2014. Development of vegetative propagation technology of teak plant in smallholder forest. Jurnal Wasian 1: 3944. [Indonesian].

Akbar MH, Ahmed OH, Jamaluddin AS, Nik Ab. Majid NM, AbdulHamid H, Jusop S, Hassan A, Yusof KH, Abdu A. 2010. Differences in soil physical and chemical properties of rehabilitated and secondary forests. Am J Appl Sci 7: 1200-1209. DOI: 10.3844/ajassp.2010.1200.1209

Auykim A, Duangsathaporn K, Prasomsinb P. 2017. Growth of teak regenerated by coppice and stump planting in Mae Moh Plantation, Lampang province, Thailand. Agric Nat Resour 51: 273-277. DOI: 10.1016/j.anres.2016.12.009

Badilla Y, Xavier A, Murilo O, Paiva HN. 2016. IBA efficiency on minicutting rooting from teak (Tectona grandis Linn F.) clones. Revista Árvore 40: 477-485. http://dx.doi.org/10.1590/0100 67622016000300011

Bailey J, Harjanto NA. 2005. Teak (Tectona grandis L.f.) tree growth, stem quality and health in coppiced plantations in Java, Indonesia. New Forest 30: 55-65. DOI: 10.1007/s11056-004-1116-5

Budiadi, Widiyatno, Ishii H. 2017. Response of a clonal teak plantation to thinning and pruning in Java, Indonesia. J Trop For Sci 29: 44-53.

Chazdon RL. 2008. Beyond deforestation: restoring forests and ecosystem services on degraded lands. Science 320: 1458-1460. DOI: $10.1126 /$ science. 1155365

Chesworth W. 2008. Encyclopedia of soil science. Springer, Nederlands DOI: 10.1007/978-1-4020-3995-9

Dawson I. 2002. Clone selection and collection. In Jaenicke H, Beniest J (eds). Vegetative tree propagation in agroforestry training guidelines and references. International Centre for Research in Agroforestry. Kenya.

Evans J, Turnbull JW. 2004. Plantation forestry in the tropics: The role, silviculture and use of planted forests for industrial, social, environmental and agroforestry purposes. Oxford University Press, Oxford.

Evans J. 2009. Sustainable management and silviculture. In Evans J (ed) Planted Forests: Uses, Impacts and Sustainability. CABI International, Wallingford.

Fageria NK. 2012. Role of soil organic matter in maintaining sustainability of cropping systems. Commun Soil Sci Plant Anal 43: 2063-2113. DOI: 10.1080/00103624.2012.697234

Gatti CR, Castaldi S, Lindsell JA, Coomes DA, Marchetti M, Maesano M, Di Paola A, Paparella F, Valentini R. 2015. The impact of selective logging and clearcutting on forest structure, tree diversity and aboveground biomass of African tropical forests. Ecol Res 30: 119-132. DOI: $10.1007 / \mathrm{s} 11284-014-1217-3$

Goh D, Monteuuis O. 2005. Rationale for developing intensive teak clona plantations, with special reference to Sabah. Bois et Foro forestry purposes 285: 5-15.

Guleria V, Vashisht A. 2014. Rejuvenation and adventitious rooting in shoot cuttings of Tectona grandis under protected conditions in new locality of Western Himalayas. Universal J Plant Sci 2: 103-106. DOI: $10.13189 /$ ujps.2014.020601

Han SI, An JY, Hwang J, Kim SB, Park BB. 2016. The effects of organic manure and chemical fertilizer on the growth and nutrient concentrations of yellow poplar (Liriodendron tulipifera Lin.) in a nursery system. For Sci Technol 12: 137-143. DOI: 10.1080/21580103.2015.1135827

Högberg KA. 2003. Possibilities and Limitations of Vegetative Propagation in Breeding and Mass Propagation of Norway Spruce [Dissertation]. Swedish University of Agricultural Sciences, Uppsala, Sweden. http://pub.epsilon.slu.se/403/1/e-version-s294.pdf.

Iskak M. 2005. Productivity of teak clonal plantation within the next 20 years. In: Siswamartana S, Rosalina U, Wibowo A (eds) Seperempat Abad Pemuliaan Jati Perum Perhutani. Pusat Pengembangan Sumber Daya Hutan. Perum Perhutani, Cepu. [Indonesian].

ITTO. 2002. ITTO guidelines for the restoration, management and rehabilitation of degraded and secondary tropical forests. ITTO Policy Development Series No 13. Yokohama: ITTO.

Jaenicke H, Beniest J . 2002. Vegetative tree propagation in agroforestry. International Centre for Research in Agroforestry. Kenya.

Júnior SA, Alexandre, Alexandre RS, Schmildt RE, Partelli FL,Ferrão, MAG, Mauri AL. 2013. Comparison between grafting and cutting as vegetative propagation methods for conilon coffee plants. Acta Scientiarum Agronomy 35: 461-469. DOI: 10.4025/actasciagron.v35i4.16917

Kaosa-ard A. 1998. Teak breeding and improvement strategies. In Kashio $\mathrm{M}$, White K (eds). The 2nd regional seminar on teak for the future, Yangon, Myanmar. Thailand, 29 May-3 June 1995, FAO-TEAKNET, 61-81.

Kollert W, Kleine M. 2017a. Introduction. In Kollert W and Kleine M (eds). The global teak study: analysis, evaluation and future potential of teak resources. International Union of Forest Research Organizations (IUFRO), Viena, Austria.

Kollert W, Kleine M. 2017b. The future of teak - what policymakers and managers need to consider. In Kollert $\mathrm{W}$ and Kleine $\mathrm{M}$ (eds). The global teak study: analysis, evaluation and future potential of teak resources. International Union of Forest Research Organizations (IUFRO), Viena, Austria.

Lamb D, Gilmour D. 2003. Rehabilitation and restoration of degraded forests. IUCN, Gland, Switzerland and Cambridge, UK and WWF, Gland, Switzerland.

Li Y, Yang Y, Ou Y, Zhang D, Liu J, Chu G, Zhang Y, Otieno D, Zhou G. 2013. Changes in forest soil properties in different successional stages in lower tropical china. PLoS ONE 8(11): e81359. DOI: 10.1371/journal.pone.0081359

Mehta P, Rana BS, Baksh H. 2013. Response of fertilizer application (N, $\mathrm{P} \& \mathrm{~N}+\mathrm{P}$ ) on seedling growth of Teak (Tectona grandis Linn.F.). J Recent Adv Appl Sci 28:31-34.

Ministry of Environment and Forestry (MoEF). 2019. Statistic of environment and forestry 2018. Ministry of Environment and Forestry, Jakarta. [Indonesian].

Naiem M. 2012. Increasing of forest productivity by intensive silviculture: the efficiency strategy of forest land use. In Nugraha A, Santoso H, Ardiansyah I, Imron AM, Sanyoto R, Awang SA, Yuwono T, dan Istoto YEB (eds) Darurat Hutan Indonesia, Mewujudkan Arsitektur Baru Kehutanan Indonesia. WanaAksara, Banten. Pp 162-183. [Indonesian].

Palanisamy K, Gireesan K, Nagarajan V, Hegde M. 2009. Selection and clonal multiplication of superior trees of Teak (Tectona grandis) and preliminary evaluation of clones. J Trop For Sci 21: 168-174.

Pandey D, Brown C. 2000. Teak: a global overview. Unasylva 51: 3-13.

Pinkard EA, Battaglia M, Mohammed CL 2007. Defoliation and nitrogen effects on photosynthesis and growth of Eucalyptus globules. Tree Physiol 27: 1053-1063. DOI: 10.1093/treephys/27.7.1053.

Sukchan S, Noda I. 2012. Improvement of soil suitability mapping for teak plantations in Northeast Thailand. In Noda I., Vacharangkura T, HimmapanW (eds). Approach to sustainable forestry of indigenous tree species in Northeast Thailand. Japan International Research Center for Agricultural Sciences (JIRCAS), Tsukuba, Japan.

Sulaeman, Suparto, Eviati. 2005. Chemistry analysis guideline for soil, plant, water and fertilizer. Indonesia Soil Research Institute, Indonesia. [Indonesian].

Tanaka N, Hamazaki T, Vacharangkura T. 1998. Distribution, growth and site requirements of teak. JARQ 32: 65-77.

Tangmitcharoen S, Nimpila S, Phuangjumpee J, Piananurak P. 2012. Two-year results of a clonal test of teak (Tectona grandis L.f.) in the 
Northeast of Thailand. In Noda I, Vacharangkura T, Himmapan W (eds). Approach to sustainable forestry of indigenous tree species in Northeast Thailand. Japan International Research Center for Agricultural Sciences (JIRCAS), Tsukuba, Japan.

Thuynsma R, Kleinert A, KossmannJ, Valentine AJ, Hills PN. 2016. The effects of limiting phosphate on photosynthesis and growth of Lotus japonicas. S A J Bot 104: 244-248. DOI: 10.1016/j.sajb.2016.03.001

Vásquez-Grandón A, Donoso PJ, Gerding V. 2018. Forest degradation: When is a forest degraded?. Forests 9(11): 726. DOI $10.3390 /$ f9110726

Wang M, Zheng Q, Shen Q,Guo S. 2013. The critical role of potassium in plant stress response. Intl J Mol Sci. 14(4): 7370-7390. DOI: 10.3390/ijms14047370.

Wang M, Shi S, Lin F, Hao Z, Jiang P, Dai G. 2012. Effects of soil water and nitrogen on growth and photosynthetic response of Manchurian ash (Fraxinus mandshurica) seedlings in Northeastern China. PLoS ONE 7 (2): e30754. DOI: 10.1371/journal.pone.0030754
Whalen JK, Chang C, Clayton GW, Carefoot JP. 2000. Cattle manure amendments can increase the pH of acid soils. Soil SciSoc Am J. 64(3):962-966. DOI: 10.2136/sssaj2000.643962x

Wichiennopparat W, Wanpinit M, Nimpila S. 2012. A preliminary result of soil improvement trial on teak in Khon Kaen, Thailand. In Noda I, Vacharangkura T, HimmapanW (eds). Approach to sustainable forestry of indigenous tree species in Northeast Thailand. Japan International Research Center for Agricultural Sciences (JIRCAS), Tsukuba, Japan.

Xu L, Dong Y, Fan Z, Kong J, Liu S, Bai X. 2013. Effects of the application of exogenous NO at different growth stages on the physiological characteristics of peanut grown in Cd-contaminated soil. J Plant Interact 9(1): 285-296. DOI: 10.1080/17429145.2013.830780

Zhou_Z, Liang K, Xu D, Zhang Y, Huang G, Ma H. 2012. Effects of calcium, boron and nitrogen fertilization on the growth of teak (Tectona grandis) seedlings and chemical property of acidic soil substrate. New Forests 43: 231-243. DOI: 10.1007/s11056-011-9276-6 